\title{
Insulin-Like Growth Factor-I and Its Binding Protein-3 in Serum: Are They Good Screening Properties for the Diagnosis of Growth Hormone Deficiency? ${ }^{1}$ )
}

\author{
Andreas Koch and Helmut-Günther Dörr
}

Abteilung für Pädiatrische Endokrinologie, Klinik für Kinder und Jugendliche der Friedrich-Alexander-Universität Erlangen-Nürnberg, Erlangen, Germany

Summary: Serum insulin-like growth factor-I and insulin-like growth factor binding protein-3 are simply-determined screening analytes if growth hormone deficiency is suspected. The analysis of growth hormone secretion using standardised stimulation tests and secretion profiles is complicated and expensive in comparison. In retrospect, we have examined the value of insulin-like growth factor-I and its binding protein-3 for the diagnostic clarification of patients with short stature $(n=117)$. In $39 / 117$ patients growth hormone secretion was investigated as ward patients. Growth hormone deficiency was diagnosed in 10 patients, for 16 patients the diagnosis was neurosecretory dysfunction. For all patients $(n=7)$ with lowered insulin-like growth factor binding protein-3 and insulin-like growth factor-I values (insulin-like growth factor binding protein-3 $<5$ th percentile, insulin-like growth factor-I $<10$ th percentile) a growth hormone disorder was proven. Conversely, however, only $3 / 10$ patients with classical growth hormone deficiency $(n=3)$ showed a lowering of both analytes. 8/10 patients with classical growth hormone deficiency and $8 / 16$ patients with neurosecretory dysfunction had at least one lowered value. Two patients showed normal values for insulin-like growth factor-I and insulin-like growth factor binding protein-3 despite biochemically proven growth hormone deficiency. The combined determination of insulin-like growth factor-I and insulin-like growth factor binding protein-3 can provide valuable help during preliminary diagnosis of patients of short stature, indicating a disturbance of the growth hormone secretion if the values are lowered. Normal values do not, however, exclude the possibility of a growth hormone deficiency. Inpatient endocrinological testing is indispensible if growth hormone deficiency is suspected.

\section{Introduction}

Growth hormone deficiency as the cause of short stature is relatively rare compared to normal variant short stature, such as familial short stature or constitutional delay of growth and puberty. Investigations of the hypothalamic-pituitary growth hormone axis are difficult and expensive in time and money.

Simple and reliable screening tests of growth hormone secretion are desirable for diagnosis of growth hormone deficiency. Insulin-like growth factor-I and its most important binding protein in serum, insulin-like growth factor binding protein-3 are possible candidates $(1,2)$.

Insulin-like growth factor-I is a polypeptide consisting of 70 amino acids, with a relative molecular mass of $M_{\mathrm{r}}=7649$ (3). The serum concentration of insulin-like growth factor-I is primarily determined by the amount of growth hormone produced $(4,5)$; in addition, the liver as main site of synthesis of insulin-like growth factor-I $(6,7)$, and nutrition $(8,9,10)$ plays an important role.

1) Parts of this publication were presented at the 90 . Anniversary of the German Society of Pediatrics in Hannover 1994.
The concentrations of insulin-like growth factor-I in serum are dependent on gender and age, or sexual development (11). Insulin-like growth factor-I shows only slight daily variations (12) due to the almost complete binding to carrier proteins, and has an effective half-life of about $12-18$ hours $(5,13,14)$.

Insulin-like growth factor binding protein-3 is the most important binding protein for insulin-like growth factorI in serum $(15,16)$. It shares the most important characteristics with insulin-like growth factor-I: Regulation by growth hormone (17), important role of liver physiology and nutrition $(18,19)$. Concentrations in serum are affected by kidney function (20) and are age-dependent $(21,22)$, daily variations are practically absent $(13,23)$.

Therefore, both analytes fulfil important preconditions:

1 . The production is directly dependent on growth hormone $(4,17,22,24)$.

2. The determination is independent of the time of day due to the long metabolic half-life (insulin-like growth factor binding protein-3: range of days $(13,22,23)$; insulin-like growth factor-I: almost a day $(7,9,10))$, and negligible circadian fluctuations $(22,23,25)$. 


\section{Commercial tests are available.}

We have examined retrospectively the value of serum insulin-like growth factor-I and insulin-like growth factor binding protein-3 determinations in the diagnosis of growth hormone deficiency.

\section{Patients and Methods}

Insulin-like growth factor-I and its binding protein-3 were determined for 117 patients with short stature (standing height $\leq 3 \mathrm{rd}$ percentile according to Swiss standards (26)) at the first visit in our outpatient clinic (from February 1993-September 1994). In retrospect, the initial insulin-like growth factor-I and insulin-like growth factor binding protein-3 values were compared with the later diagnoses, in order to ascertain the applicability of these analytes for the diagnosis of growth hormone deficiency in these patients.

Growth hormone secretion was evaluated in $39 / 117$ patients ( 31 males, 8 females, growth rate $<10$ th percentile according to Swiss standards (26)) using 2 pharmacological stimulation tests and an overnight secretion profile. None of the 39 patients had concomitant chronic diseases, karyotype was normal in all girls. The age of the children at first examination was between 3.6 and 14.3 years, the weight for height index (calculated on normal values according to Swiss standards (26)) was between $87 \%$ and $118 \%$ (min.max.). Bone age was retarded in all patients with growth hormone deficiency and neurosecretory dysfunction $(1.9 \pm 1.3$ years, mean \pm standard deviation). Growth hormone therapy was started with a dose of $0.5 \mathrm{IU} / \mathrm{kg}$ body weight/week (daily s. c. injections) in all patients with growth hormone deficiency and neurosecretory dysfunction. Mean height velocity increased significantly in the first year of growth hormone therapy from $2.6 \pm 0.9 \mathrm{~cm} /$ year (pretreatment) to $8.8 \pm 1.6 \mathrm{~cm} /$ year in the patients with growth hormone deficiency and from $3.9 \pm 1.1 \mathrm{~cm} /$ year to $7.7 \pm 1.4 \mathrm{~cm} /$ year in the patients with neurosecretory dysfunction.

Two growth hormone stimulation tests were performed (insulininduced hypoglycaemia and/or arginine test and/or clonidine test) according to standard methods (27). The interval of time between blood sampling for serum insulin-like growth factor-I/insulin-like growth factor binding protein-3 and growth hormone standard stimulation tests was 2-8 months. Growth hormone deficiency was diagnosed if no peak growth hormone level $>10 \mu \mathrm{g} / \mathrm{l}$ could be measured in either test. Growth hormone secretion profile: blood samples were taken every $20 \mathrm{~min}$ (from $8 \mathrm{p} . \mathrm{m}$. to $6 \mathrm{a} . \mathrm{m}$.) using an indwelling venous catheter. The evaluation was carried out using the Pulsar programme of Merriam and Wachter (28). Reference values of our laboratory: area above baseline $120 \pm 22.6 \mu \mathrm{g} / 1$ (mean \pm standard deviation), mean growth hormone concentration $>3 \mu \mathrm{g} / \mathrm{l}$. The diagnosis neurosecretory dysfunction was made if the growth hormone profile was pathological and growth hormone increased $>10 \mu \mathrm{g} / \mathrm{l}$ in at least one of the stimulation tests.

Insulin-like growth factor-I was determined after acid-alcohol extraction using a commercial radioimmunoassay (Serono, Freiburg, Germany). The insulin-like growth factor-I level was defined to be low if the value was less than the lower standard value $(=<10$ percentile). Table 1 shows the standard values given by the manufacturer.

Insulin-like growth factor binding protein-3 was determined using a commercial radioimmunoassay (Mediagnost, Tübingen, Germany). Insulin-like growth factor binding protein-3 levels less than the 5 th percentile were defined to be low. Table 2 shows the reference values $(5$ th -95 th percentile).

\section{Definitions}

Sensitivity: correct positive test/number of patients affected.

Specificity: correct negative test/number of patients non-affected.
Positive predictive value ( $=$ probability of disease for a patient with a pathological test result): correct positive test/total of positive tests.

Negative predictive value ( $=$ probability of exclusion of disease for a patient with a normal test result): correct negative test/total of negative tests.

\section{Results}

In $78 / 117$ patients, normal variant short stature was diagnosed due to clinical and auxological data. Growth hormone secretion was not tested in these patients. Insulin-like growth factor-I and insulin-like growth factor binding protein- 3 concentrations were either both normal $(n=47 / 78)$, or one value was decreased $(n=31 /$ 78): low insulin-like growth factor-I in 17/31 patients, low insulin-like growth factor binding protein-3 in 14/ 31 patients. Over a follow-up period of two years, there was no doubt about the diagnosis of normal variant short stature.

In 39/117 patients, growth hormone deficiency was suspected due to clinical data and growth hormone secretion was tested. The investigations showed growth hormone deficiency in 10 patients, neurosecretory dysfunction in 16 patients, and normal variant short stature in 13 patients. Insulin-like growth factor-I and insulin-like growth factor binding protein-3 values of the 39 patients are shown in figures $1-3$.

\section{Patients with growth hormone deficiency}

Three of the 10 patients had pathologically low values for both insulin-like growth factor-I and insulin-like growth factor binding protein-3. For 5 patients, one low value and one normal value was measured. Two of the

Tab. 1 Reference values of insulin-like growth factor-I (given by the manufacturer).

\begin{tabular}{lrr}
\hline Age (years) & \multicolumn{2}{c}{ Insulin-like growth factor-I $(\mu \mathrm{g} / 1)$} \\
\cline { 2 - 3 } & \multicolumn{1}{c}{ Girls } & \multicolumn{1}{c}{ Boys } \\
\hline $3-6$ & $36-168$ & $24-144$ \\
$6-9$ & $96-264$ & $72-192$ \\
$9-12$ & $120-480$ & $72-240$ \\
$12-17$ & $240-969$ & $144-672$ \\
\hline
\end{tabular}

Tab. 2 Reference values of insulin-like growth factor binding protein-3 (13).

\begin{tabular}{ll}
\hline Age (years) & $\begin{array}{l}\text { Insulin-like growth factor binding } \\
\text { protein-3 }(\mathrm{mg} / \mathrm{l})\end{array}$ \\
\hline $3-5$ & $1.52-3.32$ \\
$5-7$ & $1.66-3.59$ \\
$7-9$ & $1.82-3.80$ \\
$9-11$ & $2.12-4.26$ \\
$11-13$ & $2.22-4.89$ \\
$13-15$ & $2.31-5.24$ \\
\hline
\end{tabular}


10 patients had normal values for both insulin-like growth factor binding protein-3 (summary of clinical data see tab. 3). In all, insulin-like growth factor-I was low for $6 / 10$ patients, insulin-like growth factor binding protein- 3 was low for $5 / 10$ patients.

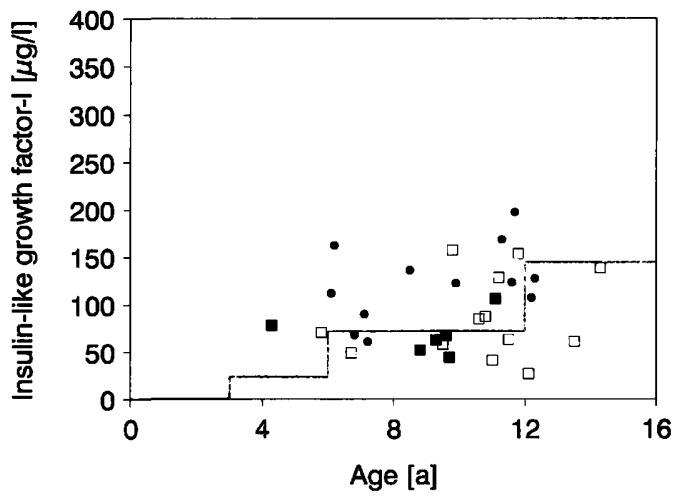

Fig. 1 Insulin-like growth factor-I values of 31 male/39 patients having growth hormone deficiency $(\square)$, neurosecretory dysfunction $(\square)$ and normal variant short stature $(\bullet)$. The line represents the 10 th percentile for normal children.

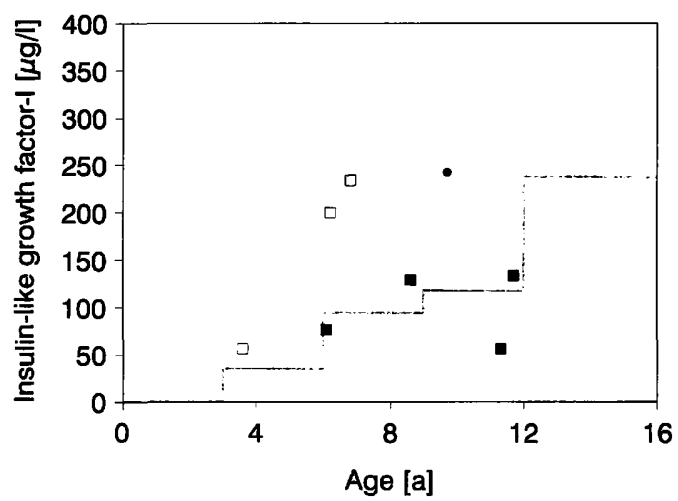

Fig. 2 Insulin-like growth factor-I values of 8 female/39 patients having growth hormone deficiency $(\boldsymbol{\square})$, neurosecretory dysfunction $(\square)$ and normal variant short stature $(\bullet)$. The line represents the 10th percentile for normal children.

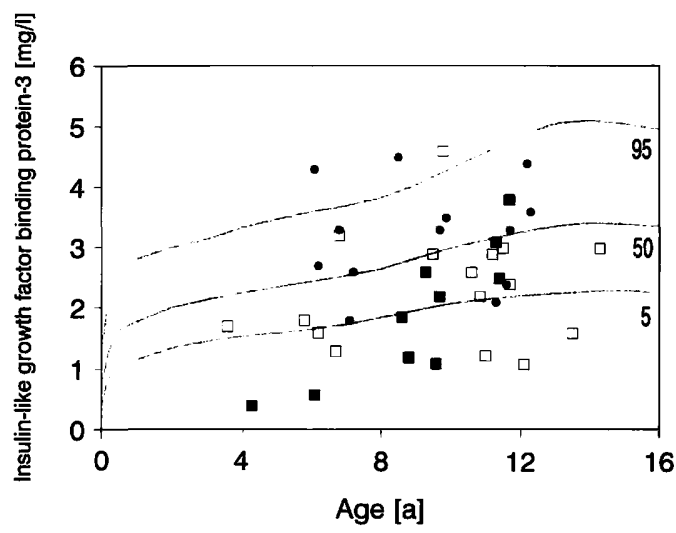

Fig. 3 Insulin-like growth factor binding protein-3 values of 39 patients having growth hormone deficiency ( $\square)$, neurosecretory dysfunction ( $\square$ ) and normal variant short stature $(\bullet)$. The lines represent the 5 th, 50th and 95th percentiles for normal children.

\section{Patients with neurosecretory dysfunction}

Four of the 16 patients had low values for both insulinlike growth factor-I and insulin-like growth factor binding protein-3. For 4 of the 16 patients, one low value and one normal value was measured. Half of the patients had normal values for both insulin-like growth factor-I and insulin-like growth factor binding protein-3. In all, $7 / 16$ patients had lowered values for insulin-like growth factor-I and 5/16 lowered values for insulin-like growth factor binding protein-3.

\section{Patients with normal variant short stature}

None of the 13 patients showed pathological values for both insulin-like growth factor-I and insulin-like growth factor binding protein-3. Five of 13 patients however, had one normal and one low value (insulin-like growth factor-I in 4/13 patients, insulin-like growth factor binding protein- 3 in $1 / 13$ patients).

According to these data (summary see tab. 4), insulinlike growth factor-I has a sensitivity (specificity) of $60 \%$ $(62.1 \%)$ as a screening analyte for growth hormone deficiency, or of $50 \%(69.2 \%)$ for a disturbed growth hormone secretion (growth hormone deficiency or neurosecretory dysfunction). The positive predictive value of insulin-like growth factor-I for a disturbed growth hormone secretion is $76.5 \%$, the negative predictive value is $40.9 \%$. For insulin-like growth factor binding protein3 we found a sensitivity (specificity) of $50 \%(79.3 \%)$ for growth hormone deficiency, or $38.5 \%$ (32.3\%) for a disturbed growth hormone secretion. The positive predictive value of insulin-like growth factor binding protein-3 for a disturbed growth hormone secretion is $90.9 \%$; the negative predictive value is $42.9 \%$.

The combination of insulin-like growth factor-I and insulin-like growth factor binding protein-3 has a sensitivity (specificity) of $30 \%(86.2 \%)$ for growth hormone deficiency and $26.9 \%(100 \%)$ for a disturbed growth hormone secretion. The positive predictive value of insulin-like growth factor-I and insulin-like growth factor binding protein-3 for a disturbed growth hormone secretion is $100 \%$, the negative predictive value is $40.6 \%$.

If only one analyte is used, the sensitivity (specificity) is $80 \%(55.2 \%)$ for growth hormone deficiency, and $61.5 \%$ $(61.5 \%)$ for a disturbed growth hormone secretion. The positive predictive value for disturbed growth hormone secretion is $76.2 \%$, the negative predictive value $44.4 \%$ (summary see tab. 5).

\section{Discussion}

There is no doubt that the basis for the growth hormone deficiency diagnosis is auxology. However, in addition to careful clinical evaluation, simple and reliable labora- 
tory screening tests of growth hormone secretion are desirable. Insulin-like growth factor-I and insulin-like growth factor binding protein-3 are suggested to be candidates for such screening analytes $(1,2)$.

Patients with growth hormone deficiency had, on average, significantly lower insulin-like growth factor-I values in serum than healthy controls $(4,11,12,29,30$, 31). Serum insulin-like growth factor-I concentrations increase after growth hormone therapy $(32,33)$. However, the use of serum insulin-like growth factor-I values as a diagnostic test for growth hormone deficiency is limited by several factors: First of all, the insulin-like growth factor-I values for healthy children in the first 6 years of life are very low, so that a distinction between lowered and still normal values is not possible for this age group (1). Secondly, there is wide scatter of insulinlike growth factor-I values for healthy controls of the same age, due to genetic influences (34), so that the separation between normal and pathological is not straightforward (1). There have been suggestions in the literature of anything between the 10th and 0.1 st percentile for the "cut-off" between normal and pathologic insulin-like growth factor-I concentrations $(11,35,36)$.

Because of the almost complete binding of insulin-like growth factor-I to carrier proteins, it is necessary to pretreat the sera (e.g. acid-alcohol extraction) to separate

Tab. 3 Clinical data of two patients with classic growth hormone deficiency and normal insulin-like growth factor-I/insulin-like growth factor binding protein-3 concentrations.

\begin{tabular}{|c|c|c|c|c|c|c|c|c|c|c|}
\hline $\begin{array}{l}\text { Patient } \\
\text { (initials) }\end{array}$ & Sex & $\begin{array}{l}\text { Chron. } \\
\text { age } \\
\text { (years) }\end{array}$ & $\begin{array}{l}\text { Bone } \\
\text { age } \\
\text { (years) }\end{array}$ & $\begin{array}{l}\text { Height } \\
(\mathrm{cm})\end{array}$ & $\begin{array}{l}\text { Height } \\
\text { (standard } \\
\text { deviation } \\
\text { score) }\end{array}$ & $\begin{array}{l}\text { Weight } \\
(\mathrm{kg})\end{array}$ & $\begin{array}{l}\text { Insulin-like } \\
\text { growth } \\
\text { factor-I } \\
(\mu \mathrm{g} / \mathrm{l})\end{array}$ & $\begin{array}{l}\text { Insulin-like } \\
\text { growth } \\
\text { factor } \\
\text { binding } \\
\text { protein-3 } \\
(\mathrm{mg} / \mathrm{l})\end{array}$ & $\begin{array}{l}\text { Growth } \\
\text { hormone peak } \\
(\mu \mathrm{g} / \mathrm{l}) \\
\text { arginine test/ } \\
\text { insulin-induced } \\
\text { hypoglycaemia }\end{array}$ & Diagnosis \\
\hline $\mathrm{KM}$ & 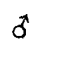 & 11.0 & 9.5 & 136 & -1.43 & 40.4 & 106 & 3.1 & $5.4 / 3.2$ & $\begin{array}{l}\text { Cranio- } \\
\text { pharyngioma }\end{array}$ \\
\hline SS & 우 & 11.6 & 10.5 & 128 & -2.96 & 26.8 & 136 & 3.8 & $5.3 / 6.1$ & $\begin{array}{l}\text { Idiopathic growth } \\
\text { hormone } \\
\text { deficiency }\end{array}$ \\
\hline
\end{tabular}

Tab. 4 Retrospective correlation of insulin-like growth factor-I and insulin-like growth factor binding protein-3 values measured initially, and later diagnosis.

\begin{tabular}{lllr}
\hline Decreased & $\begin{array}{l}\text { Growth hormone } \\
\text { deficiency }(\mathrm{n}=10)\end{array}$ & $\begin{array}{l}\text { Neurosecretory } \\
\text { dysfunction }(\mathrm{n}=16)\end{array}$ & $\begin{array}{l}\text { Normal variant short } \\
\text { stature }(\mathrm{n}=13)\end{array}$ \\
\hline $\begin{array}{l}\text { Insulin-like growth factor-I } \\
\text { Insulin-like growth factor binding protein-3 }\end{array}$ & $6(60 \%)$ & $7(36 \%)$ & $4(31 \%)$ \\
$\begin{array}{l}\text { Insulin-like growth factor-I or insulin-like } \\
\text { growth factor binding protein-3 }\end{array}$ & $5(50 \%)$ & $5(31 \%)$ & $1(8 \%)$ \\
$\begin{array}{l}\text { Insulin-like growth factor-I and insulin-like } \\
\text { growth factor binding protein-3 }\end{array}$ & $3(50 \%)$ & $4(25 \%)$ & $5(38 \%)$ \\
$\begin{array}{l}\text { Reference values: } \\
\begin{array}{l}\text { Insulin-like growth factor-I and insulin-like } \\
\text { growth factor binding protein-3 }\end{array}\end{array}$ & $2(20 \%)$ & $4(25 \%)$ & $0(0 \%)$ \\
\hline
\end{tabular}

Tab. 5 Applicability of insulin-like growth factor-I and insulin-like growth factor binding protein-3 for the diagnosis of disorders of growth hormone secretion (classic growth hormone deficiency or neurosecretory dysfunction).

\begin{tabular}{llll}
$\begin{array}{l}\text { Insulin-like } \\
\text { growth factor-I }\end{array}$ & $\begin{array}{l}\text { Insulin-like } \\
\text { growth factor } \\
\text { binding protein-3 }\end{array}$ & $\begin{array}{l}\text { Insulin-like } \\
\text { growth factor-I } \\
\text { and/or insulin-like } \\
\text { growth factor } \\
\text { binding protein-3 }\end{array}$ & $\begin{array}{l}\text { Insulin-like } \\
\text { growth factor-I } \\
\text { and insulin-like } \\
\text { growth factor } \\
\text { binding protein-3 }\end{array}$ \\
\hline $50 \%$ & $38.5 \%$ & $61.5 \%$ & $26.9 \%$ \\
$69.2 \%$ & $92.3 \%$ & $61.5 \%$ & $100 \%$ \\
$76.5 \%$ & $90.9 \%$ & $76.2 \%$ & $100 \%$ \\
$40.9 \%$ & $42.9 \%$ & $44.4 \%$ & $40.6 \%$ \\
\hline
\end{tabular}


the insulin-like growth factor-I from the binding protein. The differing methods of separation cause a marked variability in values for the many test procedures and preclude direct comparison of published results.

Our data show a clear overlap of insulin-like growth factor-I values for patients with growth hormone deficiency, neurosecretory dysfunction and children with normal growth hormone secretion. Other authors also reported such overlap. Growth hormone deficiency patients with normal insulin-like growth factor-I concentrations $(1,11,37,38)$, as well as patients with normal variant short stature and low insulin-like growth factorI levels $(1,11,39,40,41)$ have been reported.

Insulin-like growth factor binding protein-3, the most important binding protein for insulin-like growth factorI in serum $(15,16)$, shares the most important characteristics with insulin-like growth factor-I but has one important advantage compared to insulin-like growth factor-I: Pre-preparation of samples is not necessary (21, 22). Since normal values for healthy children are relatively high, low values can be easily detected. The use of insulin-like growth factor binding protein-3 therefore compares favourably to insulin-like growth factor-I (1). However, we found that insulin-like growth factor binding protein-3 was not better than insulin-like growth factor-I as a marker for a disturbed growth hormone secretion. Other authors also reported an overlap of insulin-like growth factor binding protein-3 values in children with and without growth hormone deficiency. $\mathrm{Ci}$ anfarani et al. found normal serum insulin-like growth factor binding protein-3 levels in $50 \%$ of their patients with growth hormone deficiency (36).

For our patients, we found that the single determination of either insulin-like growth factor-I or insulin-like growth factor binding protein-3 predict a disturbed growth hormone secretion in only $50-60 \%$ of the patients with growth hormone deficiency. The prediction was even lower for patients with neurosecretory dysfunction. In the literature, sensitivity and specificity of both analytes are generally judged more positively. However, recent publications found similar results (36).

Because of the relatively small number of patients it seems questionable to calculate exact percentages for sensitivity and sensibility, but the data demonstrate, that the reliability of the two analytes as diagnostic markers of a disturbed growth hormone secretion is markedly reduced.

Growth hormone secretion is not constant (42). Insulinlike growth factor-I and its binding protein-3 were measured 2-8 months before growth hormone secretion was evaluated. This fact may contribute to the low prediction value of the two analytes. However, the main endogenous factors influencing the pattern of growth hormone secretion and the response to pharmacological stimulation tests are age and pubertal maturation (43). The period of time between the two investigations was short and the majority of the children were still prepubertal. Therefore, pubertal development should not have influenced the results very much. Another exogenous factor with influence on growth hormone secretion is psychosocial distress. However, it is difficult to define psychosocial distress. In our patients, there was no indication of psychosocial short stature. Moreover, over a followup period of two years on growth hormone therapy, all patients with growth hormone deficiency or neurosecretory dysfunction responded to growth hormone with a significantly increased growth rate. Therefore, we have no doubt about the diagnosis of disturbed growth hormone secretion in these patients.

The separation of normal and pathological values at the 5th percentile for insulin-like growth factor binding protein-3 and the 10th percentile for insulin-like growth factor-I, respectively, is in accordance with the suggested cut-off value of other authors, but is to a certain extent arbitrary. Growth hormone secretion in a given population - even in a short statured subpopulation is continuous. This raises the general question of establishing cut-off values. Raising the cut-off value (for example, to the 10th percentile for insulin-like growth factor binding protein-3) would increase the sensitivity of the analyte, but the increase in sensitivity would of course be at the cost of specificity. Conversely, a lowering of the cut-off value (for example, to the 5th percentile for insulin-like growth factor-I) would effect an increase of specificity at the cost of sensitivity.

At this point, however, it must be mentioned that the criteria for the diagnosis of growth hormone deficiency are to a certain extent arbitrary, too. In early reports, a peak growth hormone concentration of $5 \mu \mathrm{g} / \mathrm{l}$ was employed to define a normal rise after pharmacological stimulation (45). Later on, the cut-off value increased to $7 \mu \mathrm{g} / 1$ and then to $10 \mu \mathrm{g} / 1$ (46). A subnormal response of serum growth hormone concentration to two pharmacological stimulation tests is still the widely used method for diagnosing growth hormone deficiency (46). This present "gold standard", however, is questioned by several authors $(42,46)$, because these non-physiological provocative tests have an increased rate of error in the diagnosis of growth hormone deficiency $(35,44,47$, 48) and a limited reproducibility (42). The measurement of spontaneous growth hormone secretion gives further information but is also limited due to variability and reduced sensitivity $(44,47,48)$. There is no completely reliable test for diagnosing or excluding growth hormone deficiency $(38,42,46)$. Therefore, it is often difficult to make a clear distinction between normal growth hormone secretion and growth hormone deficiency. However, the consequences of the diagnosis and the ex- 
pense of growth hormone therapy still require straight laboratory diagnostic criteria in addition to a careful auxological evaluation for diagnosing growth hormone deficiency (42). Therefore, pharmacological stimulation tests and spontaneous growth hormone secretion profiles cannot be abandoned at the present time (42).

\section{Conclusion}

The combined measurement of insulin-like growth factor-I and insulin-like growth factor binding protein-3 produced an abnormal result in $80 \%$ of growth hormone deficiency patients and in $61 \%$ of patients with neurosecretory dysfunction. Low values for both analytes were always associated with a disturbed growth hormone secretion, whereas normal values did not exclude a growth hormone deficiency. Therefore, we favour the combined measurement of insulin-like growth factor-I and insulin-like growth factor binding protein-3 as screening test for patients with short stature. Despite the fact that pharmacological stimulation tests have an increased rate of error in the diagnosis of growth hormone deficiency $(35,44,47,48)$ and their value is questioned by some authors (46), they are still important in clinical routine.

If biochemical analytes are considered, we suggest that the combined assessment of serum insulin-like growth factor-I and insulin-like growth factor binding protein-3 concentrations is necessary to screen outpatient short statured children for growth hormone deficiency. Subnormal values in both tests are highly suggestive of growth hormone deficiency. However, normal values do not exclude growth hormone deficiency. If auxological and clinical quantities suggest growth hormone deficiency, a careful endocrinological investigation is necessary.

\section{Acknowledgements}

We wish to thank Mrs Jutta Biskupek-Sigwart and Ms Ulrike Breunig for their expert technical assistance. We thank Mrs Patricia Schmidt for linguistic editing the manuscript.

\section{References}

1. Blum WF. Insulin-like growth factors and their binding proteins. In: Ranke MB, editor. Functional endocrinologic diagnostics in children and adolescents. Mannheim: J \& J Verlag, 1993:102-17.

2. Tassoni P, Cacciari E, Cau M, Colli C, Tosi M, Zucchini S, et al. Variability of growth hormone response to pharmacological and sleep tests performed twice in short children. J Clin Endocrinol Metab 1990; 71:230-4.

3. Rinderknecht E, Humbel RE. The amino acid sequence of human insulin-like growth factor-I and its structural homology with proinsulin. J Biol Chem 1978; 253:2769-76.

4. Furlanetto RW, Underwood LE, Van Wyk JJ, D'Ercole AJ. Estimation of somatomedin-C levels in normals and patients with pituitary disease by radioimmunoassay. J Clin Invest 1977; 60:648-57.

5. Zapf J, Kiefer M, Merryweather J, Masiarz F, Bauer D, Born $\mathrm{W}$, et al. Isolation from adult human serum of four insulin-like growth factor (IGF) binding proteins and molecular cloning of one of them that is increased by IGF I administration and in extrapancreatic tumor hypoglycemia. J Biol Chem 1990; 265:4892-8.

6. Roberts CT, Brown AL, Graham DE, Seelig S, Berry S, Gabbay $\mathrm{KH}$, et al. Growth hormone regulates the abundance of insulin-like growth factor-I RNA in adult rat liver. J Biol Chem 1986; 261:10025-8.

7. Schwander JC, Hauri C, Hapf J, Froesch ER. Synthesis and secretion of insulin-like growth factor and its binding protein by the perfused rat liver: dependence on growth hormone status. Endocrinology 1983; 113:297-305.

8. Emler CA, Schalch DS. Nutritionally-induced changes in hepatic insulin-like growth factor-I (IGF-I) gene expression in rats. Endocrinology 1987; 120:832-4.

9. Hintz RL, Suskind R, Amatayakul K, Thanangkul O, Olson R. Plasma somatomedin and growth hormone values in children with protein-calorie malnutrition. J Pediatr 1978; 92:153-6.

10. Thissen JP, Ketelslegers JM, Underwood LE. Nutritional regulation of the insulin-like growth factors. Endocrine Reviews 1994; 16:80-101.

11. Rosenfeld RG, Wilson DM, Lee PDK, Hintz RL. Insulin-like growth factors $\mathrm{I}$ and II in evaluation of growth retardation. $\mathrm{J}$ Pediatr 1986; 109:428-33.

12. Dean HJ, Kellet JG, Bala RM, Guyda HJ, Bhaumick B, Posner $\mathrm{BI}$, et al. The effect of growth hormone treatment on soma-

tomedin levels in growth hormone-deficient children. J Clin Endocrinol Metab 1982; 55:1167-73.

13. Bacter RC, Cowell CT. Diurnal rhythm of growth hormoneindependent binding protein for the insulin-like growth factors in human plasma. J Clin Endocrinol Metab 1987; 65:432-40.

14. Guler HP, Zapf J, Schmid C, Froesch ER. Insulin-like growth factors I and II in healthy man. Estimations of half-lives and production rates. Acta Endocrinol Copenh 1989; 121:753-8.

15. Baxter RC, Marin JL. Structure of the Mr 140,000 growth hormone-dependent insulin-like growth factor binding protein complex: determination by reconstitution and affinity-labeling. Proc Natl Acad Sci USA 1989; 86:6898-902.

16. Martin JL, Baxter RC. Insulin-like growth factor binding protein from human plasma: purification and characterization. $\mathrm{J}$ Biol Chem 1987; 261:8754-60.

17. Blum WF, Albertson-Wikland K, Rosberg S, Ranke MB. Serum levels of insulin-like growth factor (IGF) and IGF-binding protein 3 (IGFBP-3) reflect spontaneous growth hormone secretion. J Clin Endocrinol Metab 1993; 76:1610-6.

18. Albiston $\mathrm{AL}$, Herington $\mathrm{AC}$. Tissue distribution and regulation of the insulin-like growth factor (IGFP)-binding protein-3 messenger ribonucleic acid (mRNA) in the rat: comparison with the IGF-I mRNA expression. Endocrinology 1992; 130:497-502.

19. Ranke MB, Blum WF, Frisch $H$. The acid-stable subunit of insulin-like growth factor binding protein (IGFBP-3) in disorders of growth. In: Drop SLS, Hintz RL, editors. Insulin-like growth factor binding proteins. Amsterdam: Excerpta Medica, 1989:103-13.

20. Blum WF, Ranke MB, Kietzmann K, Tönshoff B, Mehls O. Growth hormone resistance and inhibition of somatomedin activity by excess of the insulin-like growth factor binding protein in uremia. Pediatr Nephrol 1991; 5:539-44.

21. Baxter RC, Martin JL. Radioimmunoassay of growth hormone-dependent insulin-like growth factor binding protein in human plasma. J Clin Invest 1986; 78:1504-12.

22. Blum WF, Ranke MB, Kietzmann K, Gauggel E, Zeisel HJ, Bierich JR. A specific radioimmunoassay for the growth hormone (GH)-dependent somatomedin-binding protein and its use for diagnosis of the $\mathrm{GH}$ deficiency. J Clin Endocrinol Metab 1990; 70:1292-8.

23. Jorgensen JOL, Blum WF, Moller N, Ranke MB, Christiansen JS. Circadian patterns of the serum insulin-like growth factors 
(IGF) II and IGF binding protein 3 in growth hormone deficient patients and age- and sex-matched normal subjects. Acat Endocrinol Copenh 1990; 123:257-62.

24. Zapf J, Walter H, Froesch ER. Radioummunological determination of insulin-like growth factors I and II in normal subjects and in patients with growth disorders and extrapancreatic tumor hypoglycemia. J Clin Invest 1981; 68:1321-30.

25. Minuto JP, Underwood LE, Grimaldi P, Furlanetto RW, Van Wyk JJ, Giordano G. Decreased serum somatomedin C concentration during sleep: temporal relationship to the nocturnal surges of growth hormone and prolactin. J Clin Endocrinol Metab 1981; 52:399-403.

26. Prader A, Largo RH, Molinari L, Issler C. Physical growth of Swiss children from birth to 20 years of age. First Zurich longitudinal study of growth and development. Helv Paediatr Acta 1989; 52 Suppl:1 -125.

27. Hauffa BP. Klinische und laboranalytische Meßwerte. In: Stolecke H, editor. Endokrinologie des Kindes- und Jugendalters. Berlin: Springer-Verlag, 1992:784-7.

28. Merriam GR, Wachter KW. Algorithms for the study of episodic hormone secretion. Am J Physiol 1982; 243:310-8.

29. D'Ercole AJ, Underwood LE, Van-Wyk JJ. Serum somatomedin-C in hypopituitarism and in other disorders of growth. J Pediatr 1977; 90:375-81.

30. Ranke MB, Blum WF, Bierich JR. Clinical relevance of serum measurements of insulin-like growth factors and somatomedin binding proteins. Acta Pediatr Scand 1988; 347 Suppl:114-26.

31. Zapf J, Rinderknecht E, Humbel RE, Froesch ER. Nonsupressible insulin-like activity (NSILA) from human serum: recent accomplishments and their physiologic implications. Metab Clin Exp 1978; 27:1803-23.

32. Copeland KC, Underwood LE, Van Wyk JJ. Induction of immunoreactive somatomedin-C in human serum by growth hormone: dose response relationships and effect on chromatographic profiles. J Clin Endocrinol Metab 1980; 50:690-7.

33. Rosenfeld RG, Kemp SF, Hintz RL. Constancy of somatomedin response to growth hormon treatment of hypopituitary dwarfism and lack of correlation with growth rate. J Clin Endocrinol Metab 1981; 53:611-7.

34. Kao PC, Metheny AP, Lang CA. Insulin-like growth factor-I comparisons in healthy twin children. J Clin Endocrinol Metab 1994; 78:310-2.

35. Blum WF. Die Bedeutung von IGF-I, IGF-II und IGFBP-3 für die Diagnostik des Wachstumshormonmangels. In: Ranke MB, Stolecke H, editors. Diagnostik des Wachstumshormonmangels. Ankum: Verlag Dokument und Bild, 1994:197-233.

36. Cianfarani S, Boemi S, Spagnoli A, Cappa M, Argiro G, Vaccaro $\mathrm{F}$, et al. Is IGF binding protein-3 assessment helpful for the diagnosis of growth hormone deficiency? Clin Endocrinol $1995 ; 43: 43-7$

37. Adan L, Souberbielle JC, Brauner R. Diagnostic markers of permanent idiopathic growth hormone deficiency. J Clin Endocrinol Metab 1994; 78:353-8.
38. Smith WJ, Nam TJ, Underwood LE, Bubsy WH, Celnicker A, Clemmons DR. Use of insulin-like growth factor binding protein 2 (IGFBP-2), IGFBP-3, and IGF-I for assessing growth hormone status in short children. J Clin Endocrinol Metab 1993; 77:1264-99.

39. Binoux M, Gourmelen M, Girard F. Serum levels of insulinlike growth factor (IGF) and IGF-binding protein in constitutionally short children and adolescents. Acta Endocrinol Copenh 1986; 113:145-52.

40. Cacciari E, Cicognani A, Pirazzoli P, Tassoni P, Salardi S, Capelli $\mathrm{M}$, et al. Differences in somatomedin-C between shortnormal subjects and those of normal height. J Pediatr 1985; 106:891-4.

41. Rudman D, Kutner MH, Chawla RK. The short child with subnormal plasma somatomedin C. Pediatr Res 1985; 19:975-80.

42. Cacciari EC, Tassoni P, Cicognani A, Pirazzoli P, Salardi S, Balsamo A, et al. Value and limits of pharmacological and physiological tests to diagnose growth hormone $(\mathrm{GH})$ deficiency and predict therapy response: first and second retesting during replacement therapy of patients defined as $\mathrm{GH}$ deficient. J Clin Endocrinol Metab 1994; 79:1663-9.

43. Martha PM Jr, Gorman KM, Blizzard RM, Rogol AD, Veldhuis JD. Endogenous growth hormone secretion and clearance rates in normal boys as determined by deconvolution analysis: relationship to age, pubertal status, and body mass. J Clin Endocrinol Metab 1992; 74:336-44.

44. Rocchiccioli P, Pienkowski C, Tauber MT, Uboldi F, Enjaume C. Association of pharmacological test and study of 24-hour growth hormone secretion in the investigation of growth retardation in children: analysis of 257 cases. Horm Res 1991; 35:70-5.

45. Kaplan SL, Abrams CAL, Bell JJ, Conte FA, Grumbach MM. Growth and growth hormone. I. Changes in serum level of growth hormone following hypoglycemia in 134 children with growth retardation. Pediatr Res 1968; 2:43-63.

46. Rosenfeld RG, Albertson-Wikland K, Cassorla F, Frasier SD, Hasegawa Y, Hintz RL, et al. The diagnosis of childhood growth hormone deficiency revisited. J Clin Endocrinol Metab $1995 ; 80: 1532-40$.

47. Donaldson DL, Hollowell JG, Pan F, Gifford RA, Moore WV. Growth hormone secretory profiles: variation on consecutive nights. J Pediatr 1989; 115:51-6.

48. Donaldson DL, Pan F, Hollowell JG, Stevenson JL, Gifford RA, Moore WV. Reliability of stimulated and spontaneous growth hormone $(\mathrm{GH})$ levels for identifying the child with low GH secretion. J Clin Endocrinol Metab 1991; 72:647-52.

Received June 13/November 12, 1996/February 24, 1997

Corresponding author: Dr. Andreas Koch, Klinik mit Poliklinik für Kinder und Jugendliche, Friedrich-Alexander-Universität Erlangen-Nürnberg, Loschgestraße 15, D-91054 Erlangen, Germany 
